UDK 272-9(450Venecija=163.42)“13/16”(091)

$347.67(450$ Venecija $=163.42) “ 13 / 16 ”(093.4)$

314.15(450Venecija=163.42)“13/16”(091)

Izvorni znanstveni rad

Primljeno: 1. listopada 2020.

Prihvaćeno za objavljivanje: 4. prosinca 2020.

\title{
LASSO AL MIO PADRE SPIRITUALE DA CATTARO... DUHOVNE OSOBE IZ KOTORA U MLECIMA PREMA OPORUČNIM SPISIMA HRVATSKIH ISELJENIKA \\ (14. - 17. stoljeće)
}

\author{
Lovorka ČORALIĆ
}

Hrvatski institut za povijest Opatička 10, 10000 Zagreb

lovorka@isp.hr

\begin{abstract}
Središnja tema priloga duhovne su osobe iz grada Kotora u Mlecima, njihovo djelovanje (privremeno ili trajnije) u gradu svetoga Marka, kao i njihovi prinosi crkvenim vezama između dviju jadranskih obala. Rad se zasniva na raščlambi izvorne arhivske građe pohranjene $u$ Državnom arhivu u Mlecima (Archivio di Stato di Venezia, fond: Notarile testamenti), kao $i$ na uporabi dosadašnjih spoznaja historiografije. U radu se, tragom oporučnih spisa hrvatskih iseljenika (uključivo i duhovne osobe iz Kotora) razmatra vremenski okvir njihova djelovanja, mjesta stanovanja i djelovanja (župe) te posebice njihova uključenost u nekoć brojnu i društveno važnu hrvatsku zajednicu u Mlecima.
\end{abstract}

KLJUČNE RIJEČI: Boka kotorska, Kotor, Mleci, Mletačka Republika, migracije, crkvena povijest.

\section{Uvod: opći podatci o kotorskoj zajednici u Mlecima. Cilj rada}

Hrvatska zajednica u Mlecima tijekom prošlosti činila je jednu od vodećih stranih skupina (uz Grke, Albance, Židove, Germane i druge) u gradu koji se, poradi svoje izrazite multikulturalnosti nazivao »Babilonija u malom «. ${ }^{1} \mathrm{U}$ tome kontekstu, promatrajući uže

1 O povijesti hrvatske iseljeničke zajednice u Mlecima vidi u: Lovorka ČORALIĆ, U gradu svetoga Marka: Povijest hrvatske zajednice u Mlecima, Zagreb, 2001.; Lovorka ČORALIĆ, Hrvatski prinosi mletačkoj kulturi: Odabrane teme, Zagreb, 2003. Usporedi i djela inozemnih povjesničara: Brunehilde IMHAUS, Le minoranze orientali a Venezia 1300-1510, Roma, 1997.; Andrea ZANNINI, Venezia città aperta: Gli stranieri e la Serenissima XIV-XVIII sec., Venezia, 2009.; Ermanno ORLANDO, Migrazioni mediterranee: Migranti, minoranze e matrimoni a Venezia nel basso medioevo, Bologna, 2014. U navednim knjigama vidi i brojne druge bibliografske jedinice koje se odnose na povijest djelovanja stranih etničkih zajednica u Mlecima kroz prošlost. 
zavičajno podrijetlo Hrvata sa širega područja istočnojadranske obale, pretežito su mjesto kako u brojčanom, tako i u gospodarskom i društvenom smislu, imali Bokelji. ${ }^{2} \mathrm{Na}$ osnovi podrobne raščlambe više tisuća oporuka iseljenika (zavičajem s područja od sjevera Istre do juga Crnogorskog uzmorja) u Mlecima u razdoblju od početka 15. do konca 18. stoljeća, razvidno je da su Kotorani, kada je riječ o užoj zavičajnoj pripadnosti iseljenika, činili najbrojniju regionalnu iseljeničku zajednicu. ${ }^{3}$ Raščlambom vrlo velikoga uzorka (obrađeno je više od 300 oporuka iseljenih Kotorana) opaža se da učestalija kotorska iseljavanja u Mletke započinju od dvadesetih godina 15. stoljeća; postupno rastu od četrdesetih godina toga doba, a trostruki uspon postižu u posljednjoj četvrtini 15. stoljeća. U kasnijim razdobljima polagano opada broj kotorskih iseljenika, ali tijekom čitavoga 16. stoljeća

2 O bokeljskim prekojadranskim iseljavanjima i o djelovanju Bokelja u Mlecima vidi u: Lovorka ČORALIĆ, »Iseljenici iz grada Kotora u Mlecima (XV.-XVIII. st.)«, Povijesni prilozi, sv. 17, Zagreb, 1998., str. 133-155; Lovorka ČORALIĆ, »Život i djelovanje kotorskih patricija u Mlecima od 16. do 18. stoljeća«, Radovi Zavoda za hrvatsku povijest Filozofskog fakulteta Sveučilišta u Zagrebu, sv. 31, Zagreb, 1998., str. 131-140; Lovorka ČORALIĆ, »Iz prošlosti Boke: Dobrotski rodovi i Bratovština sv. Jurja i Tripuna u Mlecima (od XVII. do početka XIX. st.)«, Radovi Zavoda za povijesne znanosti HAZU u Zadru, sv. 42, Zagreb - Zadar, 2000., str. 221-260; Lovorka ČORALIĆ, »Iz prošlosti Boke: budvanska zajednica u Mlecima (XV.-XVIII. st.)«, Povijesni prilozi, sv. 19, Zagreb, 2000., str. 125-152; Lovorka ČORALIĆ, »Peraštani u Mlecima (15.-18. stoljeće)«, u: Stjepanu Antoljaku u čast, Josip KOLANOVIĆ (ur.), Zagreb, 2003., str. 199-210; Lovorka ČORALIĆ, »Iz prošlosti Boke: Stjepan Tartaro - istaknuti hrvatski poduzetnik u Mlecima u XVI. stoljeću«, Radovi Zavoda za povijesne znanosti HAZU u Zadru, sv. 46, Zagreb - Zadar, 2004., str. 235-251; Lovorka ČORALIĆ, »Iz prošlosti Boke: Peraštani i hrvatska bratovština Sv. Jurja i Tripuna u Mlecima«, Anali Zavoda za povijesne znanosti HAZU u Dubrovniku, sv. XLII., Zagreb - Dubrovnik, 2004., str. 273-292; Lovorka ČORALIĆ, »Iz prošlosti Boke - tragom iseljenika s poluotoka Luštice u Mlecima (XVI.-XVIII. stoljeće)«, Zbornik Odsjeka za povijesne znanosti Zavoda za povijesne $i$ društvene znanosti HAZU u Zagrebu, sv. 22, Zagreb, 2004., str. 189-211; Lovorka ČORALIĆ, »Tragom oporuka bokeljskih i paštrovskih trgovaca u Mlecima (od kraja XV. do kraja XVI. stoljeća)«, Istorijski zapisi, god. LXXX, br. 1-4, Podgorica, 2007., str. 97-118; Lovorka ČORALIĆ, »Kotorski iseljenici i hrvatska bratovština Sv. Jurja i Tripuna u Mlecima (XV.-XVIII. st.)«, Croatica christiana periodica, god. XXXII, br. 61, Zagreb, 2008., str. 18-34; Lovorka ČORALIĆ, »Kotorski iseljenici u mletačkim bratovštinama kroz prošlost: o neizravnim utjecajima mletačkih vjerskih i strukovnih udruga na Bokeljsku mornaricu i druge bratimske udruge u Kotoru«, u: Zbornik radova s međunarodnog naučnog skupa »Dvanaest vjekova Bokeljske mornarice”, Jovan J. MARTINOVIĆ (ur.), Kotor, 2010., str. 55-93; Lovorka ČORALIĆ - Maja KATUŠIĆ - Maja MATASOVIĆ, »Svjedočanstva uklesana u kamenu - grobnice i nadgrobni natpisi Bokelja, Budvana i Barana u Mlecima i na otocima mletačke lagune«, Croatica christiana periodica, god. XL, br. 78, Zagreb, 2016., str. 105-138. O vezama duhovnih osoba iz Kotora u Mlecima sa hrvatskim iseljenicima napisan je i objavljen rad Lovorke ČORALIĆ, »Tragom duhovnih osoba iz grada Kotora u Mlecima (kraj XIV. st. - XVIII. st.)«, Godišnjak Pomorskog muzeja u Kotoru, sv. 54, Kotor, 2006., str. 125-148. Za ovu prigodu rad je nadopunjen novim saznanjima kako iz izvora, tako i iz historiografije. O bokeljsko-mletačkim pomorsko-trgovačkim vezama i prisutnosti Kotorana u Mlecima usporedi i prinose bokeljskih povjesničara: Miloš MILOŠEVIĆ, »Prilozi trgovačkim vezama bokeljskih pomoraca sa mletačkim tržištem«, Godišnjak Pomorskog muzeja u Kotoru, sv. 4, Kotor, 1955., str. 57-80; Niko LUKOVIĆ, »Bratovština bokeljskih pomoraca sv. Đorđa i Tripuna u Mlecima«, Godišnjak Pomorskog muzeja u Kotoru, sv. 6, Kotor, 1957., str. 33-43; M. MILOŠEVIĆ, »Nosioci pomorske privrede Kotora prve polovine XVIII vijeka«, Godišnjak Pomorskog muzeja u Kotoru, sv. 9, Kotor, 1960., str. 103-150; Miloš MILOŠEVIĆ, »Bokeljski galijuni i fregaduni XVI i XVII vijeku«, Godišnjak Pomorskog muzeja u Kotoru, sv. 11, Kotor, 1963., str. 33-50; Miloš MILOŠEVIĆ, »Bokeljske tartane XVIII stoljeća«, Godišnjak Pomorskog muzeja u Kotoru, sv. 13, Kotor, 1965., str. 5-24. Dodatne podatke vidi i u djelu Miloša MILOŠEVIĆA, Pomorski trgovci, ratnici i mecene: Studije o Boki Kotorskoj $X V$-XIX stoljeća, Vlastimir ĐOKIĆ (prir.), Beograd - Podgorica, 2003.

3 Od ukupnoga broja iseljenika sa istočne jadranske obale, u Mlecima je zabilježeno 16 posto Kotorana, 14 posto Zadrana te po osam posto barskih, splitskih i šibenskih iseljenika. Ostale zavičajne iseljeničke skupine (dubrovačka, hvarska, trogirska i dr.) zastupljene su sa znatno manjim postotnim udjelom. Usp. L. ČORALIĆ, U gradu svetoga Marka, str. 446. 
učestalost je kotorskih iseljavanja u Mletke vrlo visoka i prednjači među istovrsnim pokazateljima za druge krajeve i gradove smještene duž istočne obale Jadrana. U 17. i 18. stoljeću nastavlja se pad useljavanja iz Kotora te se uglavnom zadržava na razini s početka 15. stoljeća. Ukoliko usporedno raščlanjujemo pokazatelje kotorskih iseljavanja, kao i iseljavanja iz drugih dijelova istočnojadranske obale, opažamo izrazitu podudarnost. Naime, razdoblje unutar kojega se odvijao najveći dio prekojadranskih migracija zabilježeno je od druge polovice 15. do kraja 16. stoljeća. Razlozi tako učestalih iseljavanja Kotorana bili su svakako uključenost Kotora u Privedru Republiku unutar koje su Mleci kao glavni grad postali lakše dostupnim odredištem svih poduzetnika (ponajprije trgovaca i pomoraca) i osoba koje su trajnim zapošljavanjem težile riješiti svoju egzistenciju. S druge strane, osmanski prodori i osvajanja, koji su tada izravno ugrožavali Boku kotorsku, čime je bila otežana neophodna gospodarska komunikacija sa zaleđem, nagnali su brojno pučanstvo da iseljavanjem u prekojadranske krajeve duž Apeninskoga poluotoka pronađu sigurnost životnoga svakodnevlja. Mnogi od njih, stekavši stalno zaposlenje i zasnovavši obitelj, trajno su ostali u Mlecima. ${ }^{4}$

Kada je riječ o profesionalnoj aktivnosti Kotorana, najveći je broj njih, prema podatcima iz sačuvanih vrela (koji se poklapaju i s profesionalnom strukturom drugih hrvatskih stanovnika grada na lagunama) bio zaposlen u zanimanjima pomorskoga i obrtničkoga obilježja. Niz Kotorana (kao i drugih Bokelja) u Mlecima je bio prisutan u trgovačkim i njima srodnim poduzetničkim aktivnostima, posebice u pomorskom poslovanju. Dio te regionalne skupine iseljenika bilježimo i kao nositelje državnih i vojničkih službi, a mnogi se spominju i kao svećenici i redovnici u tamošnjim crkvenim i samostanskim ustanovama (devet posto od ukupnog broja iseljenih Kotorana kojima je zanimanje izrijekom iskazano u dokumentu). Kada je riječ o gospodarskim mogućnostima, većina pripadnika kotorske iseljeničke skupine ubrajala se u srednji i niži društveni sloj (pučane), uklapajući se na taj način u prosječnu strukturu većine Hrvata nastanjenih u Mletke. ${ }^{5}$

Uklopljenost kotorske zajednice u useljeničku skupinu svojih sunarodnjaka potvrđuje i raščlamba mjesta njihova stanovanja i obavljanja profesionalne djelatnosti. Oporučni spisi nedvojbeno potvrđuju da je preko 50 posto iseljenika iz Kotora obitavalo u istočnome gradskom predjelu Castello (poglavito u tamošnjoj središnjoj župi San Pietro di Castello) - mjestu najučestalijeg okupljanja nemletačkoga žiteljstva. U Castellu su se nalazila najčešća mjesta njihova zapošljavanja (arsenal i brodograđevni škverovi), a u srcu predjela podignuta je, upravo zaslugom i inicijativom Kotorana i drugih Bokelja, središnja ustanova okupljanja i očuvanja domovinske svijesti hrvatskih iseljenika bratovština sv. Jurja i Tripuna (Scuola degli Schiavoni, Scuola dei SS. Giorgio e Triffone, Scuola Dalmata). ${ }^{6}$

U fokusu ovoga istraživanja duhovne su osobe iz grada Kotora u Mlecima, ponajprije njihovo djelovanje privremenoga ili trajnijega obilježja. U radu je, osim postojećih historiografskih saznanja, ponajprije uporabljeno izvorno arhivsko gradivo, a to su bilježničke oporuke kotorskih i drugih iseljenika zavičajem s istočnojadranske obale (Notarile testamenti, dalje: NT), pohranjene u središnjoj mletačkoj Državnoj pismohrani (Archivio di

4 L. ČORALIĆ, »Iseljenici iz grada Kotora u Mlecima«, str. 134-135.

5 Isto, str. 136-138.

6 Isto, str. 138-139. 
Stato di Venezia, dalje: ASVe). U radu će se, tragom spomenutih arhivskih vrela, ukazati na vremenski okvir spominjanja duhovnih osoba iz Kotora u Mlecima, način njihove ubilježbe u dokumentima, mjesta stanovanja i djelovanja, kao i na crkvene odnosno redovničke dužnosti koje obnašaju. Posebna istraživačka pozornost posvetit će se oporukama kotorskih duhovnika, kao i oporukama drugih iseljenika s istočnoga Jadrana u kojima se na različite načine spominju kotorski svećenici i redovnici. ${ }^{7}$

\section{Raščlamba arhivskih spisa}

Vremenski okvir istraživanja zahvaća široko razdoblje dugoga trajanja od konca 14. do početka 17. stoljeća. Unutar toga razdoblja središnje je istraživanje usmjereno na 15. i 16. stoljeće, odnosno na doba iz kojega potječe i najviše u vrelima konkretno zabilježenih spomena kotorskih duhovnih osoba u Mlecima. Upravo na osnovi oporučnih spisa, kao ovdje poglavito korištenoga arhivskog fonda, pokazuje se da je ta profesionalna skupina iseljenika iz grada svetoga Tripuna u Mlecima najučestalije prisutna u posljednjim desetljećima 15. stoljeća te tijekom prve polovice i pedesetih godina 16. stoljeća. U kasnijim razdobljima njihov spomen u gradu na lagunama opada, što se u cijelosti poklapa s općim trendom i pokazateljima iseljavanja s istočne na zapadnu jadransku obalu u razdoblju kasnoga srednjeg i ranoga novog vijeka.

Poput njihovih drugih nekdašnjih sugrađana, i kotorski se svećenici i redovnici u mletačkim izvorima redovito bilježe oznakom zavičajnoga grada (de Catharo). Spomen njihova prezimena u oporučnim arhivskim vrelima najčešće nije ubilježen, već samo osobno i očevo ime, a među onima koja su izrijekom zapažena možemo izdvojiti prezimena Balusi i Bona. ${ }^{8}$

Duhovne osobe iz Kotora u Mlecima bile su djelatne u raznim crkvenim zvanjima i službama. Svjetovni svećenici navedeni su uobičajenom i često uopćenom i pobliže nedefiniranom oznakom prete, presbiter $i$ sacerdote, a tek je za dio njih konkretnije naveden stupanj svećeničkoga zvanja: klerik, đakon, kapelan, župnički pomoćnik, kanonik. ${ }^{9}$ Kada je riječ o redovnicima, Kotorane bilježimo među franjevcima (konventualcima i opservantima) te među pripadnicima redovničke zajednice svetoga Dominika. ${ }^{10}$ Naposljetku,

7 U radu su, kako je navedeno, korišteni oporučni spisi hrvatskih iseljenika od 14. do početka 17. stoljeća. Na oporučne spise odlučili smo se jer na izravniji način predočavaju interakciju odnosno uklopljenost kotorskih svećenika u život hrvatske zajednice u Mlecima u navedenome razdoblju.

8 Presbiter Thomas Bona de Cataro bilježi se već rane 1387. godine (B. IMHAUS, Le minoranze orientali, str. 484), a prete Martino Balusi 1492. godine (ASVe, NT, b. 672., br. 97, 1. IX. 1492.). Zahvaljujući arhivskim istraživanjima fra Ljudevita Antuna MARAČIĆA saznajemo za još nekoliko prezimena kotorskih franjevaca (konventualaca) djelatnih u Mlecima, Padovi i duž mletačke terraferme (Casellario, Grasso, Morandi i Pulzati). Usp. LJ. A. MARAČIĆ, Prekomorski susreti: veze i odnosi Provincije sv. Antuna i sv. Jeronima franjevaca konventualaca kroz stoljeća, Zagreb, 2003., str. 30, 32, 48-49, 65, 91.

9 Primjerice, clerico Martino de Cataro (ASVe, NT, b. 1155, br. 236, 28. VII. 1457.); prete Nicolaus condam Natali de Cataro acolitus (NT, b. 959, br. 296, 14. IV. 1506.); prete Trifone de Cataro capellano (NT, b. 389 , br. 224, 9. VIII. 1504.); Natale de Cataro mansionario (NT, b. 753, br. 46, 23. VI. 1500.).

${ }^{10}$ Primjerice, fra Augustin i fra Adrijan bili su pripadnici Reda propovjednika (ASVe, NT, b. 272, br. 637, 28. I. 1523.; NT, b. 641, br. 306, 20. IV. 1558.); fra Stjepan bio je brat laik Reda franjevaca opservanata (NT, b. 272, br. 628, 4. VII. 1497.). O nizu Kotorana, pripadnika Provincije svetoga Jeronima franjevaca konventualaca, piše Lj. A. MARAČIĆ u svojoj spomenutoj monografiji. 
u nekoliko primjera bilježimo i kotorske iseljenice, pripadnice mletačkih laičkih redova (trećoretkinje). ${ }^{11}$

Mjesta stanovanja duhovnih osoba iz Kotora u Mlecima određivala su se, kao i u primjeru drugih stanovnika grada na lagunama, prema gradskom predjelu (sestiere) i prema župi obitavanja (contrada, confinio). Na osnovi raščlambe velikog uzorka oporuka useljenika podrijetlom $s$ istočne jadranske obale i unutrašnjosti, saznajemo kako je velika većina stanovala u istočnom gradskom predjelu Castello. ${ }^{12}$ Napučenost toga predjela velikim postotkom hrvatskoga žiteljstva katoličke vjere zasigurno je bila i glavnim razlogom da se i kotorskim svećenicima, ponajprije onima koji su se školovali na području Veneta (Mleci, Padova) dušobrižničko djelovanje povjeravalo upravo u tamošnjim župama. Nekoliko konkretnih primjera iz izvora to nam i izravno posvjedočuje. Tako je, primjerice, jedan od prvih izrijekom zabilježenih kotorskih svećenika djelatnih u Mlecima, Toma Bona, još 1387. godine zabilježen kao svećenik u župi San Giovanni Nuovo (San Giovanni in Oleo). ${ }^{13}$ Prete Tripun iz Kotora bio je početkom 16. stoljeća kapelan nekdašnje crkve San Severo, a Nikola pokojnog Bože obnašao je, gotovo u isto vrijeme, službu đakona pri crkvi San Giovanni in Bragora. ${ }^{14}$ Uz najpoznatiji franjevački samostan - San Francesco della Vigna u predjelu Castello - vezano je djelovanje fra Frane iz Kotora, kao i kotorske trećoretkinje Klare Jurjeve. ${ }^{15}$ Naposljetku, od drugih samostanskih ustanova smještenih u predjelu Castello, kao mjesta djelovanja duhovnih osoba iz Kotora, bilježe se još i ženski samostan San Lorenzo te dominikanski samostan (San Domenico). ${ }^{16}$ Kada je riječ o drugim gradskim predjelima u gradu na lagunama, duhovne osobe iz Kotora bilježimo (prema podacima iz bilježničkih oporuka) u predjelu Cannaregio i San Marco. ${ }^{17}$

${ }^{11}$ Kao sakristanka, vjerojatno pripadnica trećoretkinja, od 1521. do 1523. godine bilježi se Kotoranka Ivana (ASVe, NT, b. 676, br. 515, 3. IV. 1521.; NT, b. 676, br. 455, 13. I. 1523.). Godine 1548. u Mlecima živi trećoretkinja Lucija (NT, b. 768, br. 92, 14. VI. 1548.), a 1553. zabilježena je suor Jacoma de Cataro, redovnica augustinskog samostana San Alvise (NT, b. 845, br. 197, 6. IV. 1553.).

12 Prema pokazateljima iz oporuka (1301. - 1801.) u kojima je podatak o mjestu stanovanja izrijekom naveden, useljenici podrijetlom s istočnojadranske obale stanovali su najučestalije u predjelu Castello (49 posto). Na središnji gradski predio otpadalo je 22 posto tih useljenika, a na Cannaregio 14 posto. Preostala tri mletačka predjela zastupljena su u strukturi obitavanja hrvatskih useljenika s po manje od deset posto (Dorsoduro sa osam posto, Santa Croce sa četiri, a San Polo sa tri posto). Usporedi: L. ČORALIĆ, U gradu svetoga Marka, str. 452. Vrlo slične pokazatelje dobivamo i kada u razmatranje uzmemo samo kotorsku iseljeničku skupinu u Mlecima. Čak 47 posto Kotorana obitavalo je u predjelu Castello, 22 posto u predjelu San Marco, a 11 posto u Cannaregiu. Na ostale dijelove grada i susjednih otoka (Murano, Giudecca, Chioggia) otpadao je znatno manji postotak (Dorsoduro sedam posto, San Polo i Santa Croce po četiri posto te otoci pet posto). Usp. L. ČORALIĆ, »Iseljenici iz grada Kotora u Mlecima«, str. 154.

${ }_{13}$ B. IMHAUS, Le minoranze orientali, str. 484.

14 ASVe, NT, b. 389, br. 224, 9. VIII. 1504.; NT, b. 959, br. 296, 14. IV. 1506. Kao svećenik crkve San Severo bilježi se 1514. godine i prete Nicolò da Cataro, ali nam na osnovi oskudnoga podatka iz izvora nije poznato je li možda riječ o istom svećeniku koji je 1506. godine vršio pastoralni rad pri crkvi San Giovanni in Bragora (NT, b. 1200, br. 150, 5. XI. 1514.).

15 ASVe, NT, b. 372, br. 47, 28. IV. 1559.; NT, b. 768, br. 92, 14. VI. 1548.

${ }^{16}$ Kotoranka Ivana, vjerojatno trećoretkinja, sakristanka je pri crkvi San Lorenzo (ASVe, NT, b. 676, br. 515, 3. IV. 1521.), a padre Matio Adriano redovnik je del ordine di San Domenico (NT, b. 641, br. 306, 20. IV. 1558.).

17 Jacoma, kći Prima iz Kotora, redovnica je mletačkoga samostana San Alvise u predjelu Cannaregio (ASVe, NT, b. 845, br. 197, 6. IV. 1553.), a Božo (Natale) Kotoranin je župnički pomoćnik u crkvi San Fantino u predjelu San Marco (NT, b. 753, br. 46, 23. VI. 1500.). 
Mleci, Padova, kao i drugi gradovi u sklopu Provincije svetoga Antuna franjevaca konventualaca, bili su mjesta učestalog djelovanja niza kotorskih fratara, pripadnika toga ogranka Reda svetoga Franje. Na osnovi podataka koje nam donosi fra Ljudevit Antun Maračić saznajemo, primjerice, da je u vodećem mletačkom samostanu konventualaca (Santa Maria Gloriosa dei Frari) 1544. godine djelovao Matheus Grasso de Catharo. Isti se franjevac 1579. godine bilježi i kao predstojnik mletačkoga samostana San Nicoletto della Lattuga. ${ }^{18}$ Prethodno navedeni podatci odnosili su se na opću raščlambu temeljnih odrednica iz života i djelovanja duhovnih osoba iz Kotora u Mlecima. U nastavku rada pozornost ću posvetiti nešto podrobnijoj raščlambi oporučnih spisa, kako onih koji se odnose na same kotorske duhovnike (izravne oporučitelje), tako i oporuka drugih iseljenika sa šireg područja istočnojadranskoga uzmorja, a u kojima su na različite načine zabilježene duhovne osobe zavičajem iz grada Kotora.

Raspolažemo trima mletačkim oporukama koje kao oporučitelji potpisuju kotorske duhovne osobe. Kronološkim redom, prva oporuka (1497.) odnosi se na brata laika Stjepana pokojnoga Nikole, pripadnika opservantskoga reda. U vrlo sažetim oporučnim navodima Stjepan izvršiteljima svoje posljednje volje (commissarima) imenuje brata Nikolu, sestre Nikolozu i Jelenu te znanca, odnosno prijatelja Ambrosia de Ocha iz Novare. Darovnice mletačkim crkvenim i samostanskim ustanovama ovdje nisu brojne (vjerojatno zbog skromnih imovnih mogućnosti kotorskoga fratra) - samostanu San Giobbe u Mlecima dariva sedamdeset dukata. Ostatak od svoje novčane imovine, koja ukupno iznosi devedeset dukata, ostavlja bratu Nikoli (sedamdeset dukata) i nećakinji Anđeli (dvadeset dukata) uz uvjet da - ukoliko Nikola i Anđela ostanu bez zakonitih potomaka - rečene svote trebaju pripasti samostanu Santa Orsola u Padovi ordinis San Francesco de observantia. ${ }^{19}$

Godine 1521. oporuku je napisala već spomenuta Kotoranka Ivana, sakristana pri mletačkom samostanu i crkvi San Lorenzo. Izvršiteljice Ivanine oporuke predstojnica su istoga samostana, mletačka plemkinja Franceschina Barbaro te tamošnja redovnica (također pripadnica ugledne mletačke obitelji) Marietta Bembo. Za svoje posljednje počivalište Ivana je odredila grobnicu u rečenom samostanu, uz napomenu da se njezino tijelo treba položiti in habito pizzochare di San Francesco. Određuje, nadalje, da se uoči njezina pokopa u crkvi San Lorenzo treba služiti trideset misa zadušnica u spomen na oporučiteljicu, a tijekom idućih deset godina u istoj će se crkvi svake godine (uz nadoknadu od pet dukata) održavati un aniversario u njezin spomen. Trećoretkinjama pri istome samostanu ostavlja jedan dukat, a kapelanu crkve, koji je obvezan sudjelovati u posljednjem ispraćaju, dariva osam libara. Kada je riječ o drugim crkvenim i samostanskim ustanovama u Mlecima, Ivana franjevcima samostana San Francesco della Vigna dariva pet dukata za služenje misa zadušnica dočim - također uz obvezu slavljenja misa - jedan dukat poklanja samostanu San Domenico u predjelu Castello. Hospitalu namjenjenom za zbrinjavanje ženske nahočadi Madonna della Pietà ostavlja jedan dukat, koliko dariva i samostanu San Giovanni Laterano u predjelu Castello. Istome samostanu sakristanka kotorskoga podrijetla dariva i unum meum crocifixum. Naposljetku, sva svoja preostala dobra, neuključena u prethodnu

18 LJ. A. MARAČIĆ, Prekomorski susreti, str. 30, 48.

19 ASVe, NT, b. 272, br. 628, 4. VII. 1497. 
raspodjelu legata, Ivana namjenjuje svećeniku koji će za pokoj njezine duše služiti zadušnice u crkvi San Lorenzo. ${ }^{20}$ Godine 1523. zabilježen je i kodicil, dodatak oporuci rečene sakristanke. U kratkim navodima koji tek neznatno mijenjaju sadržaj prvotno pisane oporuke, poništava se prije rečeni legat namijenjen hospitalu della Pietà, a samostanu San Francesco della Vigna darovnica je smanjena s prijašnjih pet na tri dukata. ${ }^{21}$

U trećoj je oporuci također riječ o kotorskoj iseljenici. Riječ je o Klari pokojnoga Ivana, udovici Anđela, splitskoga iseljenika plemenitoga (ser) podrijetla. U trenutku pisanja oporuke (1548.) Klara je bila pripadnica trećoretkinja svetoga Franje, a mjesto njezina obitavanja u posljednjim godinama života bio je hospital pri samostanu San Francesco della Vigna. Klarina je oporuka opsegom sažeta i sadrži tek nekoliko osnovnih odredaba. Izvršiteljima njezine posljednje volje imenovani su mletački građani Gerolimo Taiapiera i Zuanne Sauina. Jedinom i glavnom nasljednicom (herede residuaria) svih svojih, vjerojatno skromnih dobara, Klara je imenovala kćer Luciju, također trećoretkinju nastanjenu u hospitalu San Francesco della Vigna. ${ }^{22}$

Naspram relativno malenome broju sačuvanih i dosad istraženih izravnih oporuka kotorskih duhovnih osoba u Mlecima, istovrsna arhivska građa otkriva nam, tragom oporuka drugih useljenika s hrvatske obale Jadrana, cijeli niz konkretnih bilježenja te skupine kotorskih iseljenika u gradu na lagunama. Vremenski je raspon tih oporuka od 1457. do 1611. godine, a iseljenici u čijim se oporukama bilježe duhovne osobe iz Kotora ponajprije potječu iz samoga grada Kotora te - u manjem broju, odnosno uglavnom u pojedinačnim primjerima - i iz Budve, Bara, Splita i Skradina. Kotorani - duhovne osobe u Mlecima - u njihovim se iskazima posljednje volje bilježe kao izvršitelji oporuka, kao svjedoci prilikom njezine ovjere te kao obdarenici dijelom imovine te skupine oporučitelja. Zbog važnosti koju ta građa donosi za poznavanje navedene problematike, dokumentima te vrste valja posvetiti nešto više istraživačke pozornosti. Tako se, primjerice, u svojstvu izvršitelja oporuke Marijete, supruge Kotoranina Rade i stanovnice predjela Castello (župa San Antonin), uz njezina supruga izrijekom bilježi i Marijetin brat - prete Stephanus. Taj je kotorski svećenik obdaren sestrinim oporučnim legatom sa svotom od dva dukata. ${ }^{23}$ Oporučnom željom Splićanke Lucije, stanovnice župe San Severo u Castellu, izvršiteljem njezine posljednje volje imenovan je samo kotorski svećenik Tripun, Lucijin ispovjednik, djelatan pri istoj crkvi San Severo. Tripun je obvezan u spomen na oporučiteljicu održati mise zadušnice, za što je obdaren s tri dukata. ${ }^{24} \mathrm{U}$ oporuci Meneghine, udovice kotorskoga iseljenika Damjana, kao izvršitelj zadužen za određivanja mjesta sahrane oporučiteljice bilježi se njezin sin Matija Adriano, pripadnik Reda dominikanaca. Sva Meneghinina dobra ostavljaju se Matiji, a nakon njegove smrti, slijedom činjenice da je glavni nasljednik ujedno i redovnik, ostavština u cjelosti pripada samostanu San Domenico u predjelu Castello. ${ }^{25}$ Iako se izravno ne odnosi na duhovnu osobu iz grada Kotora, zanimljiv nam je na-

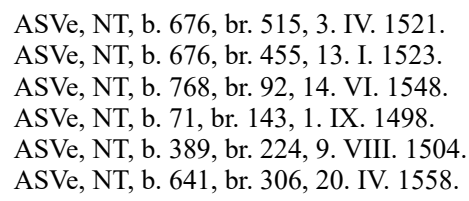


vod iz oporuke Kotoranina Vicka Ciacogne (Cicogne), privremenog žitelja župe San Giovanni Nuovo (San Giovanni in Oleo) u Castellu. Naime, Vicko pri imenovanju izvršitelja svojih oporučnih navoda spominje - uz rođaka Jakova Paskvalija - i aktualnog (u trenutku njegove smrti) kotorskoga biskupa. Taj nam podatak ujedno posvjedočuje i o ugledu koji je taj, vjerojatno privremeni iseljenik iz Kotora, zasigurno imao u svojoj matičnoj sredini. ${ }^{26}$ U idućim su navodima duhovne osobe iz Kotora zabilježene kao svjedoci oporuka iseljenika zavičajem s hrvatske obale. U prvome primjeru, datiranom u 1492. godinu, prete Mateus condam Martini de Cataro svjedok je kotorskoga iseljenika Petra Osomrića, stanovnika župe San Polo u istoimenome predjelu. ${ }^{27}$ Godine 1500. kotorski svećenik Božo (Natalis), župnički pomoćnik u crkvi San Fantino, svjedoči u dvjema oporukama svojih sunarodnjaka. U prvom primjeru potpisnica oporuke je Katarina, udovica Nikole iz Bara, stanovnica župe San Pietro di Castello, dočim je u drugom slučaju oporuka pisana od strane budvanskoga iseljenika Damjana Eustahijevog, žitelja iste župe u predjelu Castello. ${ }^{28} \mathrm{~S}$ početka 16. stoljeća kao đakon u crkvi S. Giovanni in Bragora djelatan je prete Nicolaus condam Natali de Cataro - 1506. godine Nikola svjedoči prilikom potpisivanja oporuke Felicite, supruge skradinskoga iseljenika Petra, stanovnice istoimene župe. ${ }^{29}$ Naposljetku, kada je riječ o kotorskim duhovnim osobama, svjedocima u oporukama iseljenika s istočne jadranske obale, izdvaja se i primjer svećenika Pompeja pokojnoga Luke de Pasqualis iz Kotora, svjedoka prilikom izricanja posljednje želje kotorskoga brijača Stjepana Nikolinog, žitelja župe S. Maria Formosa u predjelu Castello. ${ }^{30}$

U završnome dijelu osvrta na povezanost duhovnih osoba iz grada Kotora s njihovim sunarodnjacima s hrvatskoga uzmorja, osvrnut ćemo se na oporuke u kojima su Kotorani, svećenici i redovnici, zabilježeni kao obdarenici dijelom imovine te skupine oporučitelja. U primjeru iz 1457. godine Marija, supruga Jurja Ivanovog iz Kotora, određuje da se o njezinu trošku načini jedan kalež i potom daruje njezinu bratu kleriku Martinu. ${ }^{31}$ Odjevnim predmetima (ogrtači, pokrivala) oporučitelja Petra Osomrića iz Kotora dariva se njegov »duhovni otac« (padre meo spirituale) prete Martino Balusi da Cataro, dočim je prete Nicolò de Cataro, svećenik u crkvi San Severo, obdaren od strane uglednoga i imućnoga kotorskog iseljenika, trgovca Stjepana Tartara, s 12 dukata »per dir messe ogni di mese uno anno continuo solamente dopoi la mia morte per l'anima mia «. ${ }^{32}$ Cjelokupnom imovinom oporučitelja obdaren je, kao herede residuario, dominikanac Augustin, sin kotorskoga iseljenika Stjepana, brijača u župi Santa Maria Formosa u Castellu, dočim je fra Frano, sin Laure, supruge Kotoranina Luke, majčinim oporučnim legatom darovan sa skromnih dva dukata. ${ }^{33}$ Naposljetku, u oporuci Lukrecije Primove, kotorske iseljenice i stanovnice

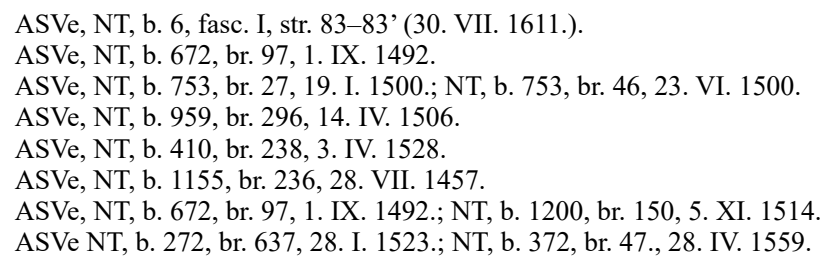


hospitala della Cha di Dio, sva imovina namijenjena je oporučiteljičinoj sestri, redovnici mletačkog samostana augustinki San Alvise. ${ }^{34}$

Prethodni navodi, sadržani u oporučnim spisima iseljenika iz zavičajem raznih dijelova istočnojadranske obale, posvjedočuju nam izrazitu povezanost duhovnih osoba iz grada Kotora sa svojim sunarodnjacima. Njihov spomen u oporukama je učestao i prisutan na raznovrstan način te nam dokazuje punu integriranost te skupine kotorskih iseljenika u zavičajnu iseljeničku zajednicu. Nadalje, prostorni okviri njihova djelovanja, izrazita povezanost sa župama predjela Castello, nova su potvrda kako je upravo ta mletačka zona, poznata po raznorodnim etničkim useljeničkim skupinama, za iseljenike s mletačkih stečevina na istočnome Jadranu predstavljala središnje područje njihova obitavanja i djelovanja.

\title{
Zaključak
}

Proučavanje prisutnosti i djelovanja duhovnih osoba zavičajem iz grada Kotora u Mlecima i na širem području Veneta zasigurno je istraživačka tema koja iziskuje mnogo veću studiju od ovoga, u konačnici ipak sažetog pregleda. Dodatna arhivska građa pohranjena u središnjoj mletačkoj pismohrani, ali i u brojnim samostanima i crkvama, nesumnjivo bi iznjedrila još cijeli niz kotorskih zaslužnika i pregaoca, pridonositelja vjerskoj poveznici između dviju susjednih jadranskih obala. Stoga se ovim prilogom, zasnovanim na iščitavanju i raščlambi odabrane arhivske građe i postojećih saznanja historiografije, nastojalo ukazati na vrijednost i istraživačku privlačnost te problematike. Ujedno, ovaj je rad i posvjedočenje o iznimnosti kotorsko-mletačkih povijesnih i kulturnih veza i prožimanja tijekom dugih stoljeća kao i važnosti koju je kotorska iseljenička zajednica, u cjelini i svojim pojedinačnim primjerima, imala u sklopu sveukupnog sagledavanja migracija s istočne na zapadnu jadransku obalu kroz prošlost.

\author{
SUMMARY \\ LASSO AL MIO PADRE SPIRITUALE DA CATTARO ...: \\ SPIRITUAL PERSONS FROM KOTOR IN VENICE ACCORDING \\ TO THE TESTAMENTS OF CROATIAN EMIGRANTS \\ $\left(14^{\text {th }}-17^{\text {th }}\right.$ CENTURY)
}

The central topic of this article are persons from Kotor (Cattaro) who lived and worked in Venice. Author used all the relevant historiographical literature regarding emigrants from Kotor in Venice, as well as the archival sources - especially notarial testaments of people from Kotor and other Eastern-Adriatic communities, which are kept in the State Archives in Venice. On the basis of the archival sources author analyzes time frame when the spiritual persons from Kotor were noted in the preserved Venetian sources, what titles

34 ASVe, NT, b. 845, br. 197, 6. IV. 1553. 
L. Čralić, Lasso al mio padre spirituale da Cattaro Duhovne osobe iz Kotora u Mlecima...

they had, where did they live and what were their activities in Venice. Author has analyzed in detail last wills of clergymen from Kotor, as well testaments of other emigrants from Kotor in which priests and monks from Kotor are mentioned. At the end, author concludes that community of emigrants from Kotor in Venice played an important role regarding the history of Croatians in Venice, and within this history spiritual persons from Kotor had a special place.

KEY WORDS: Boka kotorska, Kotor, Venice, Venetian Republic, migrations, ecclesiastical history. 